\title{
Penerapan Sistem Monitoring Lahan dan Analisa Neraca Air Klimatik Pertanian di Lahan Gambut
}

\author{
Application of Field Monitoring System and Climatic Water Balance Analysis of Agriculture on Peatlands
}

\author{
Bayu Dwi Apri Nugroho ${ }^{1 *}$, Sri Nuryani Hidayah Utami², Benito Heru Purwanto ${ }^{2}$ \\ ${ }^{1}$ Departemen Teknik Pertanian dan Biosistem, Fakultas Teknologi Pertanian, Universitas Gadjah Mada, \\ J.. Flora No. 1, Bulaksumur, Yogyakarta 55281, Indonesia \\ ${ }^{2}$ Departemen Ilmu Tanah, Fakultas Pertanian, Universitas Gadjah Mada, Jl. Flora, Bulaksumur, \\ Yogyakarta 55281, Indonesia \\ *Email: bayu.tep@ugm.ac.id
}

Tanggal submisi: 10 Januari 2019; Tanggal penerimaan: 29 Maret 2019

\begin{abstract}
ABSTRAK
Salah satu mitigasi pertanian di lahan gambut agar dapat berproduksi dengan baik adalah diterapkannya kalender tanam yang tepat, selain pengelolaan tanah dan tata air. Kondisi iklim mikro di lahan gambut belum dapat terukur secara real-time dengan interval waktu yang lebih kecil. Pelalawan merupakan daerah yang mayoritas masyarakatnya menggunakan lahan gambut untuk budidaya kelapa sawit, sehingga masih membutuhkan arahan pemanfaatan gambut yang bisa mensejahterakan masyarakat. Penelitian ini bertujuan untuk menerapkan aplikasi data klimatik real-time berbasis telemetri untuk pemantauan lahan pertanian di lahan gambut. Selain itu, juga analisis cara penentuan kalender tanam di daerah lahan gambut dengan analisa neraca air klimatik. Data series klimatik dari stasiun cuaca Pekanbaru dan sensor cuaca-tanah dipasang dilahan gambut di Desa Pelalawan dari tanggal 18 Agustus sampai 16 November 2018. Pengamatan perubahan kondisi lingkungan di lahan pertanian lahan gambut telah berhasil dilakukan. Perubahan-perubahan lingkungan klimatik dapat diamati secara kontinyu dengan interval waktu 30 menit. Data radiasi matahari menunjukkan dinamika harian, begitu juga dengan curah hujan, suhu dan kelembaban. Dinamika anasir klimatik dapat dimonitor secara langsung dan kontinyu dengan penerapan field monitoring system (FMS). Neraca air untuk padi dan jagung diperoleh berdasarkan pada kebutuhan air tanaman dan hujan efektif. Rekomendasi jadwal tanam berdasarkan analisis neraca air (surplus dan defisit) adalah padi 1-jagung-padi 2.
\end{abstract}

Keywords: Field monitoring system; iklim mikro; lahan gambut; neraca air

\begin{abstract}
Farming in peatland can produce a commodity well if it follows the right planting calendar. Microclimate conditions in the peatland cannot yet be measured in real-time within a shorter time interval. Pelalawan, a region where most of its farmers use peatland for oil palm cultivation, need guidance on applying the best method of oil palm cultivation, which is possible to improve. This study aims to apply a telemetric based (field monitoring system) real-time climatic data application to monitor the agricultural field (peatland). Climate data and weather - soil sensors were set up in Pelalawan village from August 18 to November 16, 2018. Besides, the advancement of planting calendar determination method is also done for peatland farming with a climatic water balance analysis. The change in peatland farming has been successfully observed and measured. The changes in the climatic environment can be observed continuously within a time interval of 30 minutes. Sun radiation data show a significant fluctuation shift from day to day. It also occurs for rainfall, temperature and humidity data. Climatic
\end{abstract}

DOI: http://doi.org/10.22146/agritech.43507

ISSN 0216-0455 (Print), ISSN 2527-3825 (Online) 
data fluctuation can be monitored directly and continuously with a Field Monitoring System (FMS) application. Water balance for paddy and corn is obtained based on Plant Water Need and Effective Rain. The recommended schedule according to water balance analysis (surplus and deficit) is paddy 1 - corn - paddy 2 .

Keywords: Field monitoring system; microclimate; peat land; water balance

\section{PENDAHULUAN}

Luas lahan gambut di Provinsi Riau sekitar 3,89 juta hektar dari 6,49 juta hektar total luas lahan gambut di Sumatera. Saat ini diperkirakan lahan gambut yang telah terdegradasi sekitar 2.313.561 hektar atau $59,54 \%$ dari total luas lahan gambut di Provinsi Riau. Sisanya sekitar 1.037.020 hektar dari lahan tersebut dimanfaatkan untuk budidaya tanaman seperti kelapa sawit, tanaman pangan dan hortikultura (Wahyunto dkk., 2013). Lahan gambut berpeluang untuk dimanfaatkan sebagai areal pertanian yang produktif. Komoditas yang dapat dikembangkan antara lain tanaman pangan seperti: padi, palawija; tanaman hortikultura seperti jeruk, lidah buaya, dan berbagai sayuran; dan tanaman perkebunan seperti karet, kelapa, kopi, dan kelapa sawit. Pengembangan lahan gambut harus memperhatikan aspek biofisik lahan, sosial ekonomi dan lingkungan. Keterpaduan antara ketiga aspek tersebut diharapkan dapat berdampak terhadap keberlanjutan sistem pertanian di lahan gambut (Maftuah dkk., 2015).

Keberadaan ekosistem hutan dan lahan gambut saat ini semakin terus terancam. Karena eksistensinya gambut juga terancam oleh bencana kebakaran dan kegiatan penambangan. Dampak tidak langsung kebakaran hutan dan gambut adalah peningkatan potensi perubahan iklim global sebagai akibat pertambahan emisi gas rumah kaca yang dilepaskan ke udara (Masganti, 2013).

Teknologi pemanfaatan lahan gambut untuk pertanian dibutuhkan lima strategi khusus yaitu penyiapan lahan, pengelolaan air, ameliorasi dan pemupukan, pemilihan komoditas, dan pengaturan pola tanam. Penyiapan lahan bertujuan untuk menciptakan kondisi tanah menjadi baik, gembur dapat ditanami dengan mudah, lahan bersih dari gulma, dan aerasi tanah baik sehingga perakaran tanaman menjadi baik. Pemilihan komoditas dapat mempengaruhi keberhasilan budidaya tanaman pertanian di lahan gambut. Komoditas tanaman yang ditanam di lahan gambut sebaiknya yang adaptif untuk mengurangi input sarana produksi yang dibutuhkan sehingga terjadi efisiensi biaya. Komoditas hortikultura (sayuran dan buah-buahan) memiliki nilai ekonomis yang lebih tinggi dari tanaman pangan, tetapi memerlukan teknik budidaya yang lebih rumit (Yuliani,
Air sangat dibutuhkan sejak awal pertumbuhan dan pada saat pengisian biji karena itu ketersediaan air merupakan faktor pembatas yang paling menentukan pada usaha tani lahan kering. Tidak semua lahan dapat ditanami sepanjang tahun sebab kemampuannya memanfaatkan air tanah terbatas, walaupun faktor tanah dan potensi biologisnya memungkinkan atau tanamannya peka terhadap cekaman kekeringan (Musa, 2012). Jumlah kebutuhan air memiliki hubungan yang erat dengan evapotranspirasi tanaman (ETo dan curah hujan $(\mathrm{CH})$ efektif. Jika jumlah $\mathrm{CH}$ efektif lebih besar dari evapotranspirasi tanaman, maka kebutuhan air tercukupi. Sebaliknya, jika jumlah curah hujan lebih rendah dari evapotranspirasi tanaman, maka kebutuhan air tidak tercukupi (Rizqiyah dkk., 2013).

Pada prinsipnya pengaturan pola tanam di lahan gambut bertujuan mengurangi lamanya waktu tanah dalam keadaan terbuka yang memicu terjadinya emisi. Relay planting adalah salah satu contoh penerapan pola tanam yang memungkinkan tanah gambut tidak terbuka saat penggantian tanaman berikutnya. Pengaturan pola tanam dan pola usaha tani merupakan alternatif yang dapat diterapkan untuk meningkatkan intensitas pertanaman dan memperpendek masa bera. Pola usahatani yang diterapkan petani dapat berupa monokultur seperti padi - bera, sayur - sayuran atau multi kultur seperti padi + palawija/sayuran , sayuran + palawija , sangat tergantung pada tipologi lahan (Yuliani, 2014). Metode untuk mendapatkan pola tanam dan pola usahatani yang sesuai adalah dengan analisa neraca air klimatik. Neraca air ini sangat berkaitan dengan kejadian hujan di wilayah setempat. Menurut (Purnama dkk., 2012), neraca air merupakan suatu neraca masukan dan keluaran dari suatu tempat dalam suatu periode tertentu. Hasil analisa ini akan dapat digunakan untuk menentukan jadwal awal musim tanam dan pola tanam yang sesuai dengan kondisi iklim.

Tujuan dari penelitian ini adalah penerapan aplikasi data klimatik real - time berbasis telemetri (field monitoring system) untuk pemantauan lahan pertanian di lahan gambut. Selain itu, juga penerapan jadwal dan pola tanam di daerah lahan gambut dengan analisa neraca air klimatik. 2014) 


\section{METODE PENELITIAN}

\section{Lokasi Penelitian}

Penelitian ini dilakukan di Desa Pelalawan Kecamatan Pelalawan di Kabupaten Pelalawan Provinsi Riau. Gambar 1 menunjukkan lokasi penelitian dari Desa Pelalawan.

Keseluruhan luas lahan di Kecamatan Pelalawan, perkebunan mendominasi luas lahan yang di gunakan pada Kecamatan Pelalawan. Perincian penggunaan lahan di Kecamatan Pelalawan dapat dilihat pada tabel berikut.

Berdasarkan Tabel 1 dapat dilihat sebagian wilayah yang berada di Kecamatan Pelalawan digunakan sebagai perkebunan dengan luas wilayah yang dipakai sekitar $35.591,89$ ha dengan persentase $78,3 \%$. Sedangkan untuk sawah $0,5 \%$, ladang $12 \%$, tegalan $4,3 \%$, dan lainnya 4,9\%. Dapat dijelaskan bahwa kondisi lahan yang ada di kecamatan pelalawan adalah lahan gambut dengan ketebalan yang beragam, lahan marginal ini diolah dan dikembangkan untuk lahan pertanian dengan kearifan lokal masyarakat. Desa Pelelawan, Kecamatan Pelalawan, Kabupaten Palalawan yang mempunyai

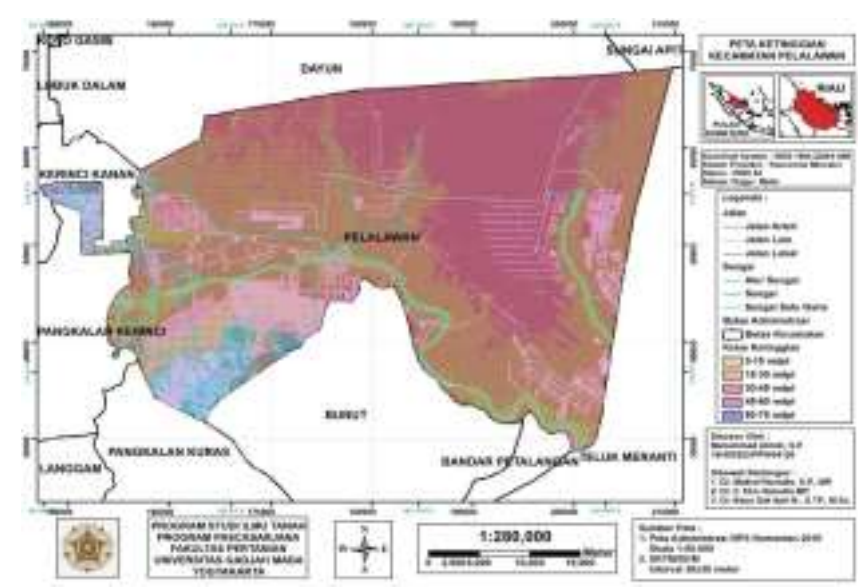

Gambar 1. Lokasi Penelitian di Desa Pelelawan

Tabel 1. Penggunaan Lahan di Kecamatan Pelalawan

\begin{tabular}{lll}
\hline Jenis Lahan & Luas Wilayah (ha) & Persentase (\%) \\
\hline Sawah & 249,00 & 0,55 \\
Ladang & $5.446,83$ & 11,98 \\
Tegalan & $1.938,13$ & 4,26 \\
Perkebunan & $35.591,89$ & 78,30 \\
Lainnya & $2.230,49$ & 4,91 \\
Jumlah & $45.456,34$ & 100,00 \\
\hline
\end{tabular}

Sumber: Data Sekunder, 2018 kawasan APL (Area Penggunaan Lain) seluas 4000 ha. Lahan gambut ini kering di musim kemarau, dan tergenang saat musim hujan.

\section{Metodologi}

\section{Penerapan sistem monitoring lahan (cuaca- tanah)}

Untuk melakukan optimalisasi kondisi lahan dan air, data parameter lingkungan biofisik (cuaca-tanah) diperoleh melalui penerapan sistem monitoring. Adapun skema sistem monitoring yang akan diterapkan sesuai dengan Gambar 2, dan alat ini dipasang pada plot percobaan di Desa Pelalawan.

Gambar 2 merupakan skema monitoring yang akan diterapkan di lapangan, ada 5 sensor yang terpasang di lahan, yaitu sensor radiasi matahari (Pyranometer), arah dan kecepatan angin (anemometer), kelembaban dan suhu udara, hujan dan kelembaban tanah (termasuk suhu dan daya hantar listrik tanah). Seluruh sensor terkoneksi dengan data logger Em50. Pengukuran dilakukan setiap 30 menit sekali dan seluruh data akan tersimpan di data logger tersebut. Data tersebut akan diambil secara rutin setiap hari oleh FieldRouter dan dikirim ke server melalui jaringan internet GSM. Sebagai pengguna, dapat mengakses seluruh data baik berupa data numeric, grafik maupun gambar/ foto melalui website yang telah dibangun. Dengan sistem ini, data kondisi lingkungan antara lain curah hujan, suhu, kelembaban dan penyinaran matahari di lapang dapat dimonitor secara kontinyu dari tanggal 18 Agustus sampai 16 November setiap harinya.



1. Solar Radiation Sensor

2. Precipitation sensor (Rain gauge)

3. Anemoneter

4. Humidity/ Air Temperature sensor

5. Soil Moisture sensor

6. Em50 Datalogger

Gambar 2. Skema sistem monitoring

Sumber: Nugroho \& Arif (2018) 


\section{Neraca Air Klimatik}

Neraca air lahan merupakan neraca air untuk penggunaan lahan pertanian secara umum. Neraca ini bermanfaat dalam mempertimbangkan kesesuaian lahan pertanian, mengatur jadwal tanam dan panen; mengatur pemberian air irigasi dalam jumlah dan waktu yang tepat. Pengairan merupakan proses pemberian air pada tanah untuk memenuhi kebutuhan tanaman sehingga diperlukan analisis seberapa besarnya kebutuhan air untuk tanaman. Perhitungan kebutuhan air tanaman didasarkan oleh besarnya nilai evapotranspirasi potensial $\left(E T_{0}\right)$ dengan software Cropwat 8.0. Data anasir iklim yang diperlukan untuk melakukan perhitungan menggunakan Cropwat 8.0 adalah data iklim bulanan yang sudah di rerata meliputi radiasi matahari, kecepatan angin, temperatur maksimum dan temperatur minimum, curah hujan dan kelembaban udara.

$$
E T=K C \times E T O
$$

Dimana :

$E T=$ evapotranspirasi tanaman $(\mathrm{mm} / \mathrm{hari})$

$E T O=$ evaporasi tanaman acuan/tetapan ( $\mathrm{mm} /$ hari)

$K c=$ koefisien tanaman

\section{HASIL DAN PEMBAHASAN}

\section{Kondisi Iklim di Riau}

Kondisi iklim di Riau diperoleh dari data klimatologi; curah hujan dan suhu dari stasiun cuaca Simpangtiga
Pekanbaru dari bulan Januari 2014 sampai bulan Oktober 2018.

Gambar 3 menampilkan data klimatik bulanan yang diperoleh dari stasiun Pekanbaru/ Simpangtiga dari bulan Januari 2014 sampai Oktober 2018. Data klimatik meliputi data hujan dan data suhu yang terdiri dari suhu minimum, suhu maksimum dan suhu ratarata. Dari grafik terlihat bahwa setiap bulan terjadi hujan walaupun berfluktuatif, dari intensitas rendah sampai tinggi. Dari Januari 2014, intensitas hujan berfluktuatif diantara 100-500 $\mathrm{mm} /$ bulan, dengan intensitas tertinggi terjadi pada bulan November tahun 2016. Pada musim kemarau antara April-September juga terjadi hujan dengan intensitas rendah sampai tinggi, sehingga tidak ada perbedaan yang signifikan antara musim hujan dan musim kemarau. Sedangkan data suhu menunjukkan bahwa suhu rata-rata fluktuatif antara $24-30{ }^{\circ} \mathrm{C}$, sedangkan suhu minimum $21^{\circ} \mathrm{C}$ yang terjadi pada bulan Februari 2017, dan suhu maksimum $34^{\circ} \mathrm{C}$ yang terjadi pada bulan Mei 2017.

\section{Penerapan sistem monitoring lahan}

Penerapan sistem untuk mendapatkan data cuaca dan parameter tanah dan air secara berkelanjutan dari lahan. Data yang tersimpan di data logger diambil secara manual, dalam interval waktu tiga hari sekali. Data yang tersimpan dalam data logger diatur dengan interval pengambilan data setiap 30 menit sekali. Berikut ini adalah metode pengambilan data yang sudah tersaji dalam bentuk data harian.

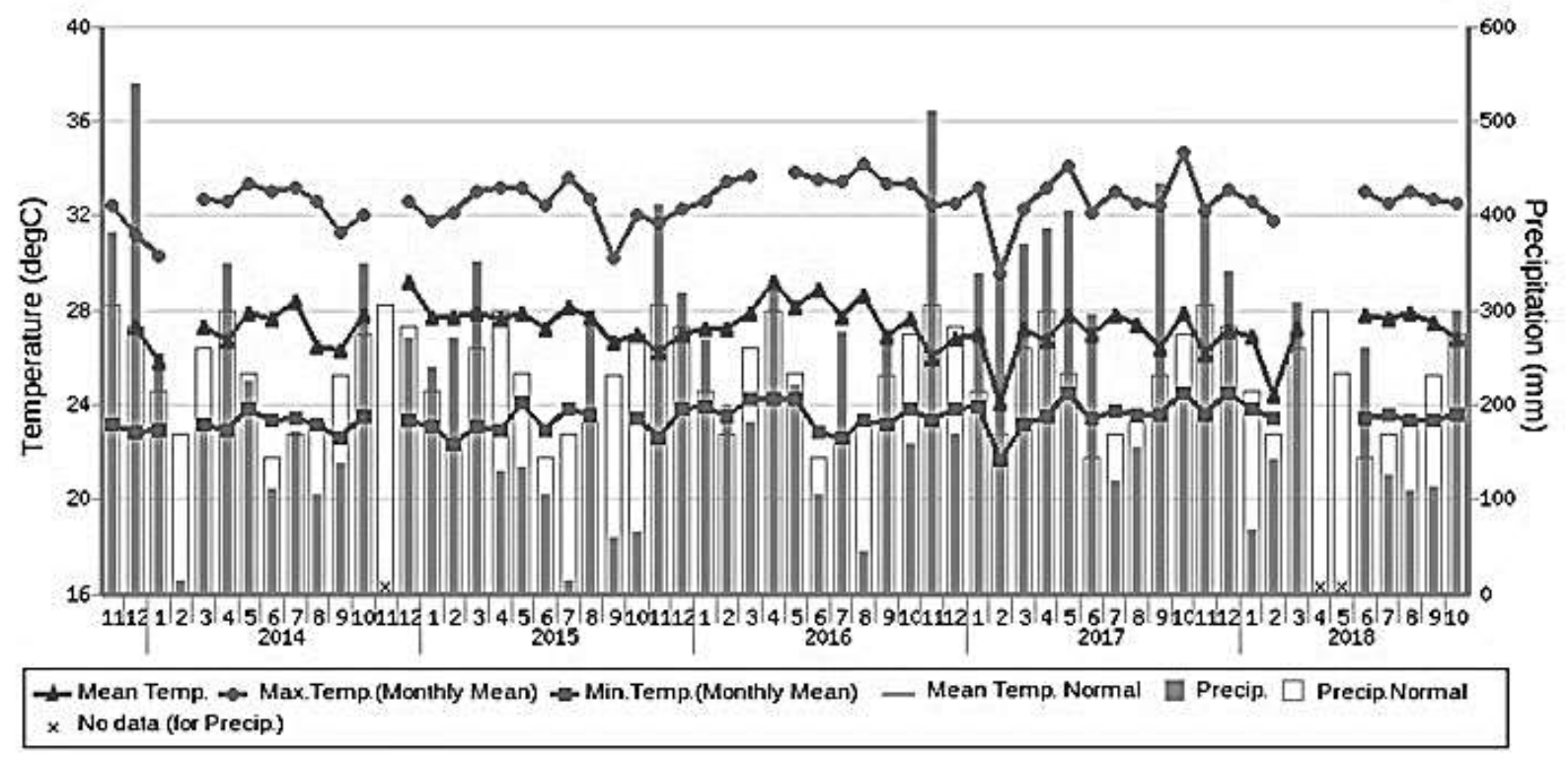

Gambar 3. Kondisi Iklim di Pelalawan

Sumber: Data Analisis 


\section{Pengambilan data}

Pengambilan data dari data logger menggunakan software $\mathrm{ECH} 2 \mathrm{O}$ utility yang diunduh secara gratis dari website www.decagon.com (Gambar 4).

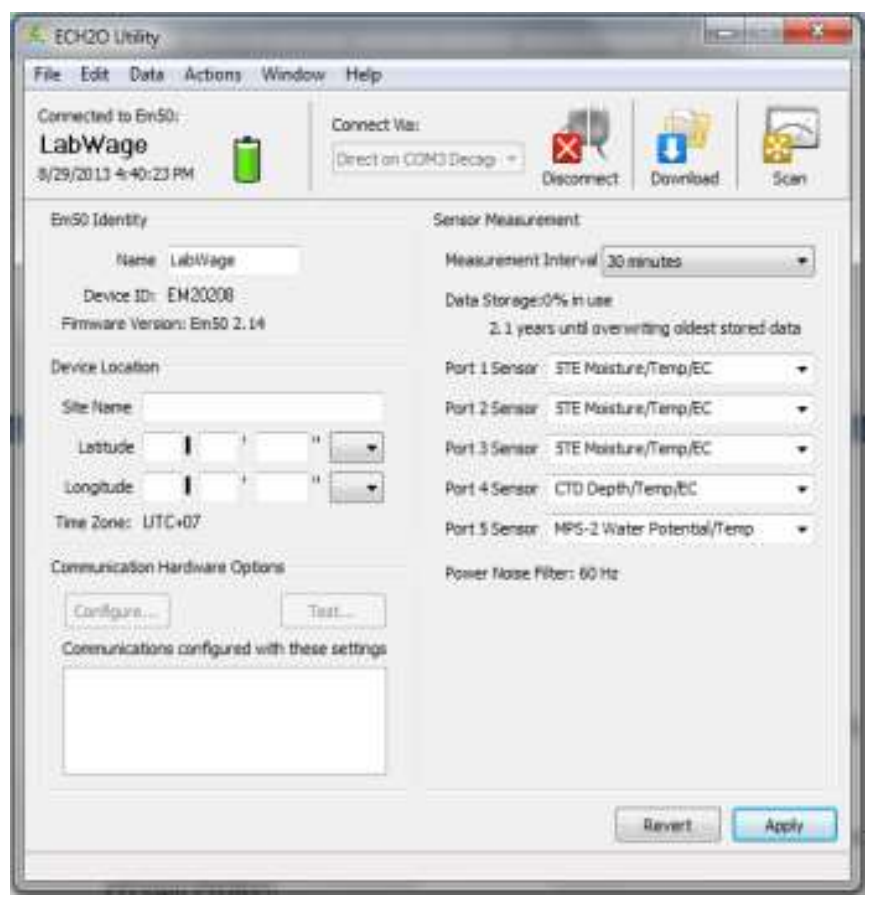

Gambar 4. Software ECH2O utility

\section{Pengunduhan data}

Setelah data diunduh dan dalam format CSV dengan interval 30 menit untuk masing-masing sensor, kemudian dilakukan pengelompokan data dari interval 30 menit menjadi data harian, dan data tersebut tersaji dalam Gambar 5-7.

Radiasi matahari sangat berpengaruh pada pertumbuhan tanaman, Gambar 5 menunjukkan trend radiasi matahari yang fluktuatif selama pengamatan di lokasi penelitian. Nilai radiasi tertinggi terjadi pada awal September. Intensitas radiasi matahari sangat berpengaruh terhadap proses dalam tanaman, seperti proses fotosintesis, kemasakan biji buah dan pembungaan pada tanaman. Intensitas radiasi matahari mempunyai pengaruh terhadap perbedaan suhu udara pada berbagai waktu pengamatan. Intensitas cahaya dan suhu udara merupakan komponen iklim yang dapat diamati. Pada skala kecil, iklim mikro sangat mudah untuk diamati kerena lingkupnya yang tidak terlalu luas. Iklim mikro adalah faktor-faktor kondisi iklim setempat yang memberikan pengaruh langsung terhadap fisik pada suatu lingkungan. Iklim mikro merupakan iklim di lapisan udara terdekat permukaan bumi dengan ketinggian \pm 2 meter (Bunyamin. Z \& Aqil, 2010).

Gambar 6 menunjukkan data curah hujan dari bulan Agustus hingga November, curah hujan tertinggi terjadi pada akhir bulan Oktober. Data curah hujan berkaitan erat dengan kebutuhan air pada tanaman. Tanaman padi membutuhkan curah hujan minimal

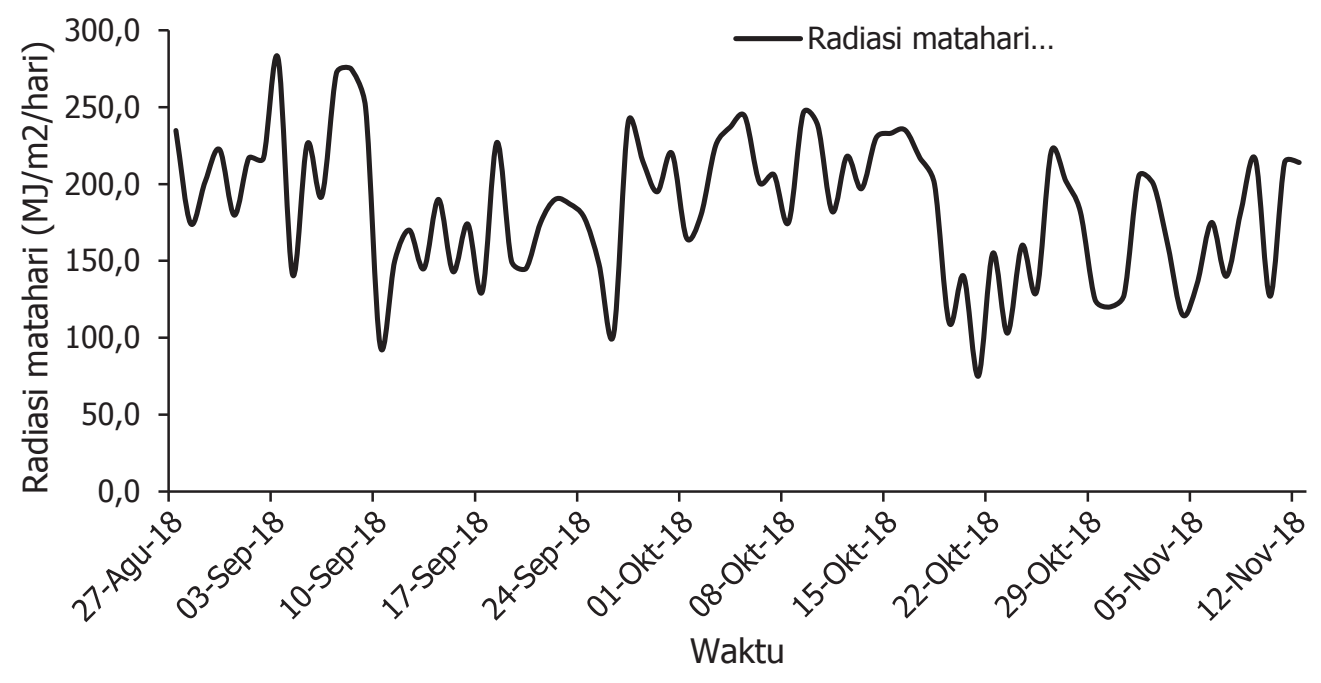

Gambar 5. Data Penyinaran matahari 


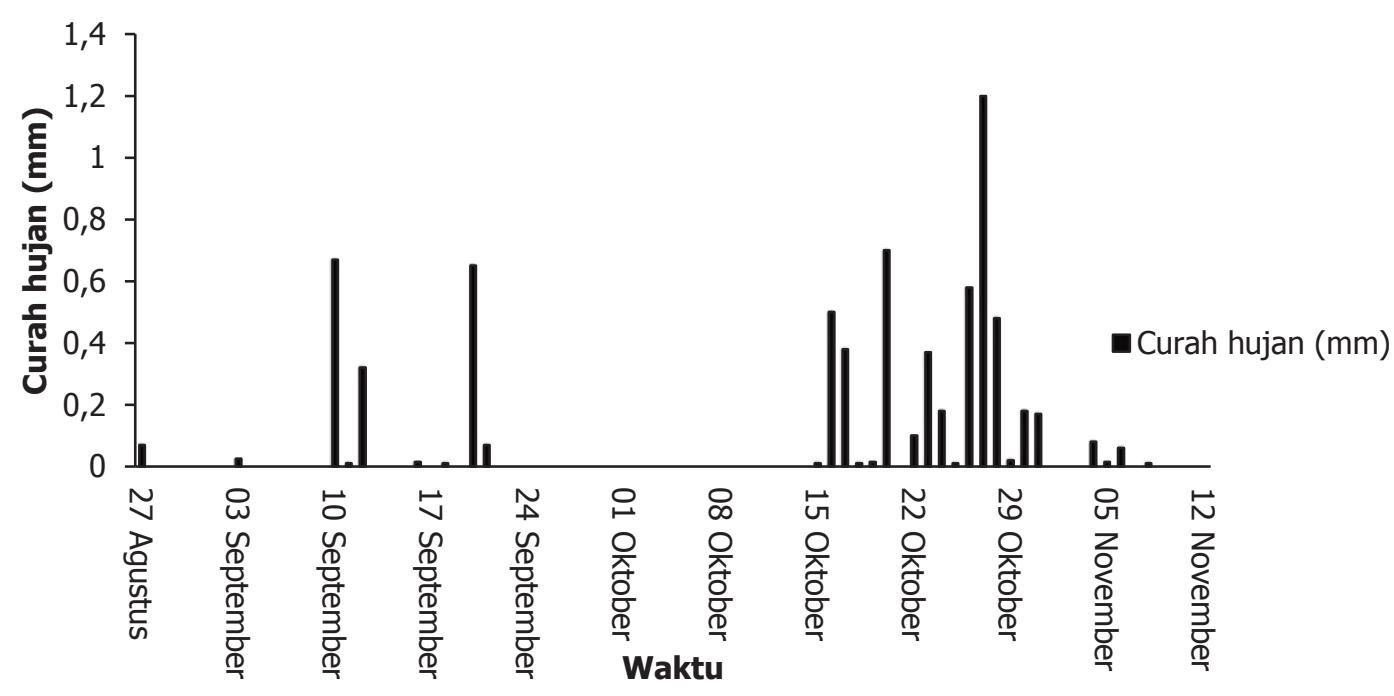

Gambar 6. Data curah hujan

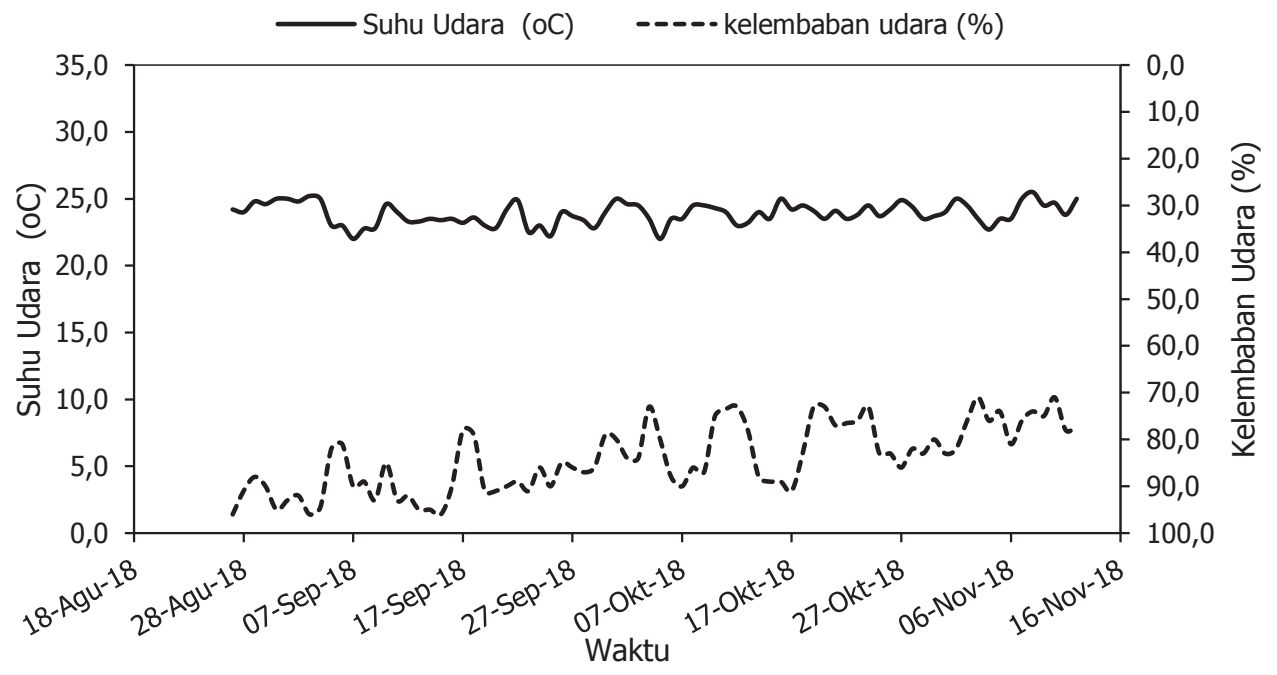

Gambar 7. Data suhu dan kelembaban

sebesar $200 \mathrm{~mm} /$ bulan sedangkan untuk jagung sebesar $100 \mathrm{~mm} /$ bulan, apabila curah hujan rendah maka kebutuhan air tanaman harus dipenuhi dengan bantuan irigasi teknis, sedangkan, curah hujan yang ideal untuk tanaman jagung pada umumnya antara 200 sampai dengan $300 \mathrm{~mm}$ per bulan atau yang memiliki hujan tahunan 800 sampai dengan 1200 mm (Riwandi dkk., 2014).

Berdasarkan pengamatan yang telah dilakukan terlihat suhu dan kelembaban udara mengalami kenaikan dan penurunan. Kelembaban erat hubungannya dengan ketersediaan air. Saat kelembaban terlalu tinggi, seluruh pori-pori tanah akan terisi air hingga jenuh (Tjasyono, 2004). Gambar 7 menunjukkan suhu dan kelembaban tertinggi yang dicapai selama pengamatan sebesar $30^{\circ} \mathrm{C}$ dan $70 \%$. Temperatur udara yang dibutuhkan untuk pertumbuhan tanaman jagung adalah $23-27$ ${ }^{\circ} \mathrm{C}$ (Riwandi dkk., 2014). Kondisi suhu dan kelembaban udara pada suatu daerah berkaitan dengan jenis tanaman yang dapat tumbuh pada tempat tersebut. Tanaman padi (Oryza sativa L.) mempunyai syarat pertumbuhan pada suhu udara $22-27^{\circ} \mathrm{C}$ untuk dataran rendah, karena tanaman padi tumbuh baik di iklim yang berhawa panas dan mengandung uap air. Berdasarkan trend suhu dan kelembaban udara pada Gambar 7 di daerah lahan pertanian lahan gambut di Desa Pelalawan memenuhi syarat tumbuh untuk tanaman padi dan jagung. Pertumbuhan suatu tanaman sangat 
dipengaruhi oleh faktor lingkungan seperti cahaya matahari, temperatur, kelembaban serta kondisi tanah (Tjasyono, 2004).

\section{Neraca Klimatik}

Penentuan kebutuhan air tanaman (ETC) dilakukan sebelum menentukan kalender tanam padi dan jagung. Penentuan komoditas ini didasarkan mayoritas konsumsi masyarakat serta pola tanam di Desa Pelalawan. Hasil kali antara nilai evapotranspirasi potensial (ETo) dengan koefisien masing-masing tanaman (Kc) pada tiap fase pertumbuhan adalah nilai kebutuhan air tanaman (ETC) (Persamaan 1). Nilai ETo diperoleh dari data anasir iklim yang meliputi suhu, kelembaban udara, radiasi matahari, dan kecepatan angin seperti tersaji pada Tabel 2.

Dari Tabel 2 dapat dilihat bahwa curah hujan prediksi masih mengalami defisit air pada musim kemarau, yaitu pada bulan Juli-Agustus. Sehingga dengan mengetahui neraca klimat ini maka dapat

Tabel 2 Nilai lebih (surplus) dan kurang (defisit) untuk evaporasi $(E T C)$

\begin{tabular}{lllll}
\hline No & Bulan & ETc $(\mathrm{mm} /$ bulan) & Surplus & Defisit \\
\hline 1 & January & 116,25 & 338,25 & 265,53 \\
2 & February & 107,52 & 299,23 & 234,15 \\
3 & March & 121,52 & 264,98 & 203,14 \\
4 & April & 118,2 & 165,8 & 120,36 \\
5 & May & 113,77 & 67,73 & 38,69 \\
6 & June & 106,5 & 27 & 5,64 \\
7 & July & 114,08 & $-46,08$ & $-56,96$ \\
8 & August & 127,41 & $-67,66$ & $-77,22$ \\
9 & September & 130,8 & $-35,8$ & -51 \\
10 & October & 139,5 & 126 & 83,52 \\
11 & November & 128,7 & 252,55 & 191,55 \\
12 & Desember & 113,15 & 281,35 & 218,23 \\
\hline
\end{tabular}

Tabel 3. Kebutuhan air tanaman (Padi-Jagung-Padi)

\begin{tabular}{lllll}
\hline No & Eto $(\mathrm{mm} /$ bulan $)$ & Kc & Etc $(\mathrm{mm} /$ bulan $)$ & Keterangan \\
\hline 1 & 116,25 & 0,3 & 34,875 & Padi \\
2 & 107,52 & 0,5 & 53,76 & \\
3 & 121,52 & 1,05 & 127,596 & \\
4 & 118,2 & 0,7 & 82,74 & \\
5 & 113,77 & 0,3 & 34,131 & Jagung \\
6 & 106,5 & 0,3 & 31,95 & \\
7 & 114,08 & 1,2 & 136,896 & \\
8 & 127,41 & 0,35 & 44,5935 & \\
9 & 130,8 & 0,3 & 39,24 & Padi \\
10 & 139,5 & 0,5 & 69,75 & \\
11 & 128,7 & 1,05 & 135,135 & \\
12 & 113,15 & 0,7 & 79,205 & \\
\hline
\end{tabular}

digunakan untuk membuat rekomendasi pola tanam yang cocok untuk lahan gambut di Desa Pelalawan. Tanaman yang menjadi rekomendasi adalah tanaman padi dan jagung.

Perhitungan kebutuhan air dari tanaman ini menggunakan nilai ETo yang telah diperoleh pada Tabel 2 di atas kemudian dikalikan dengan nilai $K c$ tanaman. Untuk lebih jelasnya disajikan dalam Tabel 3.

Kalender tanam diperoleh dari selisih antara curah hujan efektif dengan kebutuhan air tanaman (padi dan jagung). Apabila nilai simpangan semakin kecil, maka semakin baik kualitas tanaman padi dan jagung. Analisis neraca air dapat digunakan untuk menentukan besarannya $(\mathrm{mm})$ dan waktu terjadinya defisit air di dalam tanah. Sehingga dengan mengetahui defisit air tanah dapat ditentukan waktu tanam dan waktu pemberian irigasi (Simanjuntak dkk., 2016). Berdasarkan analisa neraca air pada penelitian ini, maka ditentukan rekomendasi kalender tanam yang sesuai untuk daerah lahan pertanian lahan gambut di Desa Pelalawan seperti terlihat pada Gambar 8.

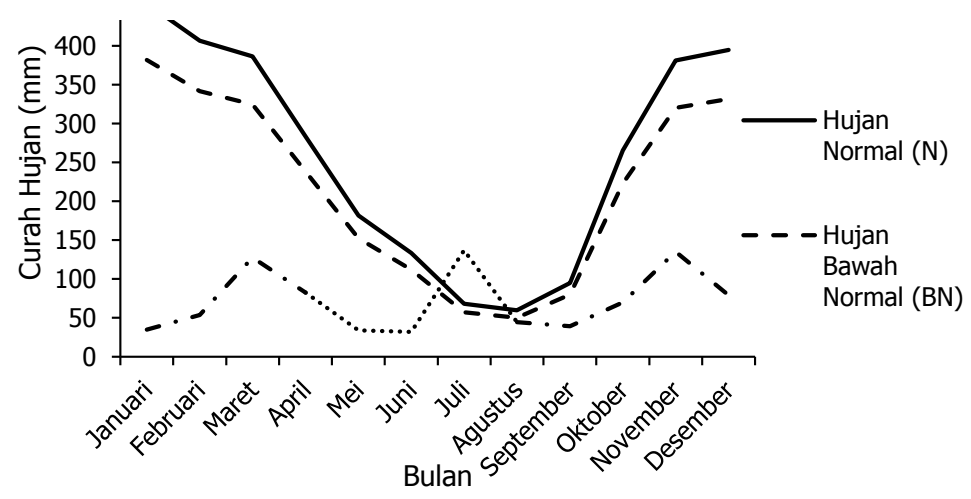

Gambar 8. Grafik neraca air tanaman rekomendasi 1 
Neraca air bermanfaat untuk melengkapi gambaran umum dari keadaan air pada suatu daerah (presipitasi, evapotranspirasi, kandungan dan perubahan kelembaban tanah); menilai kemampuan suatu daerah untuk ditanami melalui pendugaan kebutuhan air bagi tanaman, menguji hubungan iklim atau cuaca dengan hasil produksi tanaman (Ayu dkk., 2013). Tanaman padi dan jagung merupakan dua dari sekian jenis tanaman yang termasuk dalam tanaman pangan utama. Rekomendasi jadwal tanam berdasarkan analisis neraca air (surplus dan defisit) seperti terlihat pada Gambar 8 adalah Padi1 - Jagung - Padi2. Seperti terlihat pada Gambar 8 pada bulan tujuh (Juli) curah hujan cukup rendah sehingga disarankan untuk menanam jagung. Pola tanam dapat menunjang program diversifikasi pangan, yaitu dengan memilih kombinasi jenis komoditi yang akan diusahakan pada lahan sawah dengan memanfaatkan sumberdaya yang tersedia (Setiani dkk., 2015). Penentuan kalender tanam ini sangat membantu petani untuk meminimalisir terjadinya gagal panen akibat dari pola tanam yang salah.

\section{KESIMPULAN}

Pengamatan perubahan kondisi lingkungan di lahan pertanian lahan gambut telah berhasil dilakukan. Perubahan-perubahan lingkungan klimatik telah dapat diamati secara kontinyu dengan interval waktu 30 menit. Data radiasi matahari menunjukkan fluktiatif perubahan yang signifikan dari hari per hari, begitu juga dengan curah hujan, suhu dan kelembaban. Fluktuasi data-data klimatik dapat dimonitor secara langsung dan kontinyu dengan penerapan field monitoring system. Rekomendasi pola tanam berdasarkan analisis neraca air (surplus dan defisit) adalah padi 1 - jagung padi 2. Sedangkan jadwal tanamnya dimulai padi $1 \mathrm{di}$ bulan Januari, Jagung di bulan Mei dan Padi 2 di bulan September.

\section{UCAPAN TERIMA KASIH}

Ucapan terima kasih kami sampaikan kepada Badan Restorasi Gambut (BRG) dan kelompok tani Desa Pelalawan Riau. Penelitian ini merupakan Pilot Project Hibah dari Badan Restorasi Gambut (BRG) kepada Universitas Gadjah Mada tahun 2017-2018

\section{KONFLIK KEPENTINGAN}

Penulis menyatakan bahwa artikel ini asli, belum pernah dipublikasikan, dan bebas dari konflik kepentingan.

\section{DAFTAR PUSTAKA}

Ayu, I. W., Prijono, S., \& Soemarno. (2013). Evaluasi Ketersediaan Air Tanah Lahan Kering di Kecamatan Unter Iwes, Sumbawa Besar. Jurnal Pembangunan Dan Alam Lestari, 4(1), 18-25.

Bunyamin. Z, \& Aqil, M. (2010). Analisis Iklim Mikro Tanaman Jagung. Proseding Pekan Serelia Nasional, 978-979. Retrieved from Sistem Pertanaman Sisipan, jagung, iklim mikro\%0APendahuluan.

Maftuah, E., Norr, M., Hartatik, W., \& Nursyamsi, D. (2015). Pengelolaan dan Produktivitas Lahan Gambut Untuk Berbagai Komoditas Tanaman. Jurnal Litbang Tanaman Pertanian. Retrieved from https://balittra.litbang. pertanian.go.id/index.php/publikasi/28-monograf/1663pengelolaan-dan-produktivitas-lahan-gambut-untukberbagai-komoditas-tanaman.

Masganti. (2013). Teknologi Ramah Lingkungan dalam Budidaya Kelapa Sawit di Lahan Gambut Terdegradasi. Jurnal Sumberdaya Lahan, 9, 97-106. DOI: http://dx.doi. org/10.2018/jsdl.v9i2.6594

Musa, N. (2012). Penentuan Masa Tanam Jagung ( Zea mays L.) Berdasarkan Curah Hujan dan Analisis Neraca Air di Kabupaten Pohuwato. JATT, 1, 23-27.

Nugroho, B. D. A., \& Arif, C. (2018). Field Monitoring System and Adaptation Strategy of System of Rice Intensification ( SRI ) Cultivation Against Regional Climate Change in the Southern Part of Indonesia. International Symposium on Machinery and Mechatronics for Agriculture and Biosystems Engineering, (May), 28-30.

Purnama, I. L. S., Trijuni, S., Hanafi, F., Aulia, T., \& Razali, R. (2012). Analisis Neraca Air di DAS Kupang dan Sengkarang (Novi Rahmawati, Ed.). Yogyakarta: Percetakan Pohon Cahaya.

Riwandi, Handajaningsih, M., \& Hasanudin. (2014). Teknik Budidaya Jagung dengan Sistem Organik di Lahan Marjinal. In Suhendro (Ed.), UNIB PRESS (1st ed.). Bengkulu: UNIB PRESS.

Rizqiyah, F., Wirosoedarmo, R., \& Widiatmono, B. R. (2013). Dampak Pengaruh Perubahan Iklim Global terhadap Produksi Kedelai (Glicine max L Merril) di Kabupaten Malang. Jurnal Keteknikan Pertanian Tropis Dan Biosistem, 1, 7.

Setiani, N., Zakaria, W. A., \& Adawiyah, R. (2015). Analisis Keuntungan Usahatani antar Pola Tanam Di Lahan Sawah Desa Tata Karya Kecamatan Abung Surakarta Kabupaten Lampung Utara. JIIA, 3(2), 122-129. DOI: http://dx.doi.org/10.23960/jiia.v3i2.\%25p

Simanjuntak, B. H., Agus, Y. H., \& JP, Y. S. (2016). Kajian Ketersediaan Air Tanah untuk Penentuan Surplus-Defisit Air Tanah. Prosiding Konser Karya Ilmiah, 2, 113-124.

Tjasyono, B. (2004). Klimatologi umum (Ed.2, 2004). Bandung: ITB. 
B. D. A. Nugroho dkk. /Agritech 39 (2) 2019 108-116

Wahyunto, Ritung, S., Nugroho, K., Sulaeman, Y., Tafakresnanto, H. C., Suparto, \& Sukarman. (2013). Atlas lahan gambut terdegradasi (Desember 2; E. Agus, Fahmuddin; Noor, M.; Sarwani, Muhrizal; Husen, Ed.). Jakarta: IAARD PRESS.
Yuliani, N. (2014). Pendahuluan Fungsi Lahan Gambut. Prosiding Seminar Nasional Inovasi Teknologi Pertanian Spesifik Lokasi, (4), 361-373. Retrieved from http:// kalsel.litbang.pertanian.go.id/ind/images/pdf/ semnas2014/41_nurmili.pdf 